\title{
Effect of No-Till Farming and Straw Mulch on Spatial Variability of Soil Respiration in Sloping Cropland
}

\author{
Yingchen Li', Cuicui Hou', Qibo Wang', Yingying Chen', \\ Jianmin Ma ${ }^{1 *}$, Zaman Mohammad ${ }^{2}$ \\ ${ }^{1}$ Henan Normal University, Xinxiang 453007, China \\ ${ }^{2}$ Soil and Water Management and Crop Nutrition Section, Joint FAO/IAEA Division of Nuclear Techniques \\ in Food and Agriculture, Department of Nuclear Sciences and Applications, International Atomic Energy Agency, \\ Vienna International Centre, PO Box 100, 1400 Vienna, Austria
}

Received: 10 May 2016

Accepted: 18 July 2016

\begin{abstract}
The two major techniques of conservation agriculture - no-till and straw mulch - are widely used in agricultural activities. Many studies have investigated the response of soil respiration to conservation agriculture. However, there are few studies estimating soil $\mathrm{CO}_{2}$ emissions in sloping cropland. For this research we selected typical sloping cropland in China's semiarid Loess Plateau region. The spatial heterogeneity of soil respiration under different tillage and straw mulch was investigated using an LI-8100A soil carbon flux measuring system from October 2013 to September 2014. Soil respiration showed a strong seasonal pattern under all treatments, with the highest values in July $\left(3.42-8.26 \mu \mathrm{mol} \mathrm{m}^{-2} \mathrm{~s}^{-1}\right)$ and the lowest in January $\left(0.16-0.33 \mu \mathrm{mol} \mathrm{m}^{-2} \mathrm{~s}^{-1}\right)$. No-till increased soil respiration by increasing soil temperature and soil moisture, while straw mulch decreased soil moisture and had the tendency to increase annual total carbon emissions, and straw incorporation had the highest annual total soil carbon emissions (992 $\left.\mathrm{g} \mathrm{C} \mathrm{m}^{-2}\right)$. The slope stage had a visible effect on soil respiration, and soil respiration rates increased in the following order: lower $>$ middle $>$ upper positions under different treatments. The relationship between soil respiration and soil moisture was linear under all treatments; the exponential model was more suitable for simulating the relationship between soil respiration and soil temperature. Temperature sensitivity $\left(Q_{10}\right)$ values under different treatments ranged from 1.94 to 2.63 , and the difference among tillage and straw mulch treatments as a whole was not significant. However, the $\mathrm{Q}_{10}$ values had a tendency to decrease from summit to foot in tillage treatments, and no-tillage would reduce spatial variability of $\mathrm{Q}_{10}$ values.
\end{abstract}

Keywords: no-till, straw mulch, straw incorporation, Loess Plateau, slope position

*e-mail: majm95@126.com 


\section{Introduction}

Soil microbial respiration, which produces approximately 80 to $100 \mathrm{Pg} \mathrm{CO}_{2}-\mathrm{C}$ annually, plays an important role in the global carbon cycle [1-2]. Small changes in $\mathrm{CO}_{2}$ emissions due to land use changes and farm management practices may have a major effect on atmospheric $\mathrm{CO}_{2}$ concentrations [3-4]. Agricultural land represents about $40-50 \%$ of the Earth's land surface [5], and is likely to increase in the future due to increasing food demand for rapidly growing human populations [6]. Agricultural activity and farm management practices can have either a positive effect on soil quality by sequestering $\mathrm{C}$ in soil or enhancing the release of soil $\mathrm{C}$ as $\mathrm{CO}_{2}$ into the atmosphere [7-8].

Conservation practices, including no-till and covering surface soil with crop residues (mulching), play important roles in controlling soil erosion, enhancing crop productivity and improving soil fertility [9]. Several studies have reported the effect of no-till and straw mulch on soil microbial respiration and carbon storage $[4,7,10-12]$. Some researchers have reported that tillage accelerates soil disturbance, destroys the stability of soil aggregates, and promotes $\mathrm{CO}_{2}$ emissions [13], while others have reported no such effect of tillage management on soil $\mathrm{CO}_{2}$ emissions [4, 14-16] or reduced soil respiration [17]. Straw mulch obviously affects soil $\mathrm{CO}_{2}$ emissions by changing soil physical and chemical properties [18], and straw decomposition itself also release some amounts of $\mathrm{CO}_{2}$ [19-20]. In general, straw mulch is reported to stimulate soil microbial activity and respiration, which leads to increased $\mathrm{CO}_{2}$ emissions to the atmosphere [2123]. On the other hand, some authors suggest that the long-term application of crop residues increase the content of small macroaggregates $(>250 \mu \mathrm{m})$ in $0-10 \mathrm{~cm}$ depth, which then lead to the accumulation of high carbon and nitrogen concentrations, which in turn serve as a substrate for microbial growth and subsequent $\mathrm{CO}_{2}$ emissions [21]. However, some researchers did not see such positive effects of straw mulch on soil microbial respiration [10] or reduced soil respiration [24]. Such a lack of response of added straw on $\mathrm{CO}_{2}$ emissions could be due to several factors: 1) straw mulch decreases soil temperature, 2) residues could serve as a barrier for $\mathrm{CO}_{2}$ emissions from soil to the atmosphere, and 3) residue decomposition rate was low due to minimum residue-soil contact [24-25].

Soil microbial respiration is reported to be variable in space, especially in sloping land possibly due to differences in soil chemical and biological properties, plant types and community, soil moisture, and soil redistribution [12, 2628]. Most studies have reported that soil temperature and moisture affect soil microbial respiration as first-order and second-order, respectively, meaning that each degree rise in soil temperature influences soil microbial respiration $[12,26]$. Soil erosion, transportation, and deposition by water and tillage drastically affect the distribution of soil organic $\mathrm{C}$, which then influences the exchange of carbon between the pedosphere and the atmosphere [28-30]. Van Hemelryck et al. [28] measured soil respiration shortly after an erosion event on depositional and comparable sites without sedimentation and found a slightly increased mineralization of soil organic carbon at depositional sites. But this effect was only important in the short term. The results correspond to the findings of a laboratory study [31] where a similar but more pronounced increase in soil microbial respiration after soil deposition due to a soil disturbance that exposed protected $\mathrm{C}$ in soil aggregates to microbial decomposition. In contrast to these results, Bajracharya et al. [32] and Parkin et al. [27] did not find any significant differences in soil respiration measured at different slope positions in the field. Despite these inconsistent results, soil redistribution was found to have a great effect on the spatial variability of soil respiration [26]. Tillage and application of straw as mulch can affect soil redistribution, changes in soil properties, and soil temperature and moisture [7, 10, 19, 24], which affect the spatial variability of soil respiration. However, to our knowledge there few studies have been conducted on the effect of tillage and application of straw as mulch on the spatial variability of soil respiration from sloping cropland.

The main objectives of this study were: 1) to determine and compare soil $\mathrm{CO}_{2}$ emissions under different tillage and straw mulch treatments to better understand $\mathrm{C}$ dynamics in soil and 2) to investigate the influence of different tillage and straw mulch management on spatial variability of soil respiration.

\section{Materials and Methods}

\section{Site Description and Soil Characteristics}

This study was conducted at Lingbao Experimental Station of Soil Erosion and Landscape Ecology of Henan Normal University, located in western Henan Province, China $\left(34^{\circ} 31^{\prime} \mathrm{N}, 110^{\circ} 59^{\prime} \mathrm{E}\right)$. The study site is in the Loess Plateau in northern China, with a total area of $628,000 \mathrm{~km}^{2}$ [33]. This soil in the region has suffered serious degradation by soil erosion due to its sloping landscape and intensive agricultural activities [34]. Soil conservation practices, including minimum or zero tillage and mulching, may have the most potential to reduce soil erosion and protect carbon loss in the plateau [35]. This area is a typical Loess Plateau area with temperate continental monsoon climate of four seasons. Annual mean temperature and annual mean precipitation are $13.8^{\circ} \mathrm{C}$ and $640 \mathrm{~mm}$. Most precipitation is distributed from July to August with an average frost-free period of 206 days.

\section{Experimental Design}

The study site was in sloping cropland with an average slope degree of $12^{\circ}$ and with corn as the monoculture crop. Corn was planted in late April 2013 and harvested after four months in September, followed by leaving the site fallow till the next corn planting. Two tillage treatments were carried out: conventional moldboard plough tillage and no tillage. Three methods of returning corn straw were 
set up in a conventional moldboard plough tillage plot: no corn straw application (CT), corn straw incorporated into soil (TSI), and corn straw mulch on soil surface (TSM). In the no-till treatment, two methods of returning corn straw were set up: no corn straw application (NT) and corn straw mulch on soil surface (NTM). Each plot was about $5 \times 30 \mathrm{~m}$ (along the slope direction). In each plot, the slope location was used as a subsidiary-factor and three general landscape elements with three replicates were identified (summit, shoulder, and foot position), resulting in nine locations per treatment. Following treatment applications, soil respiration was measured using an automated soil $\mathrm{CO}_{2}$ flux system (LI-8100A, LI-COR, USA) equipped with a portable chamber (Model 8100-103). Soil $\mathrm{CO}_{2}$ flux rates were calculated on the basis of a linear increase in $\mathrm{CO}_{2}$ concentrations in the chamber over time. A PVC collar (20.3 cm in diameter and $10 \mathrm{~cm}$ in height) was inserted 8 $\mathrm{cm}$ into the soil surface halfway between the corn rows in each location and three days before the first measurement. Living weeds inside the collars were carefully clipped from the soil surface. The collars were removed before corn sowing and were re-inserted into soil surface after corn sowing. Soil $\mathrm{CO}_{2}$ flux rates were measured for a oneyear period from 4 October 2013 to 20 September 2014; measurements were made from twice a week to monthly, between 8:30 and 11:30 local time on each sampling day. Daily soil temperature and moisture in $0-5 \mathrm{~cm}$ soil depth near each collar were measured during each measurement of soil respiration using a handle thermocouple probe (Omega, USA) and frequency domain reflectometry (FDR), respectively.

Soil respiration rates from the monitoring period were fitted to soil temperature and soil water content with exponential and linear functions given in equations (1) and (2) to describe the dependence of soil respiration on soil temperature and soil water content.

$$
\begin{array}{r}
\mathrm{R}=\mathrm{a} \times \mathrm{e}^{\mathrm{bT}} \\
\mathrm{R}=\mathrm{AW}+\mathrm{B}
\end{array}
$$

...where $\mathrm{R}, \mathrm{T}$, and $\mathrm{W}$ are soil respiration, soil temperature, and soil water content, respectively, and a, b, A, and B are constant coefficients. The $\mathrm{Q}_{10}$ values of soil respiration based on equation (3) were calculated as:

$$
\mathrm{Q}_{10}=\exp (10 \mathrm{~b})
$$

Annual soil $\mathrm{CO}_{2}$ emissions were calculated by interpolating the average $\mathrm{CO}_{2}$ flux rate between sampling dates, and computing the sum of the products of the average flux rate and the time between respective sampling dates for each measurement period [3-4] as follows:

$$
\mathrm{SR}=\sum \mathrm{F}_{\mathrm{m}, \mathrm{k}} \Delta \mathrm{t}_{\mathrm{k}}
$$

... where $\mathrm{SR}$ is total soil $\mathrm{CO}_{2}$ emitted in the measurement season $\left(\mathrm{g} \mathrm{C} \mathrm{m}^{-2}\right), \mathrm{F}_{\mathrm{m}, \mathrm{k}}$ is the average $\mathrm{CO}_{2}$ flux rate over the interval $t_{k+1}-t_{k}$ as recorded by the LI-8100A Soil CO Flux System, and $\Delta \mathrm{t}_{\mathrm{k}}=\mathrm{t}_{\mathrm{k}+1}-\mathrm{t}_{\mathrm{k}}$ is the number of days between each field measurement within the season.

\section{Statistical Analyses}

The main and interactive effects of tillage, straw mulch and slope position treatments on soil temperature,
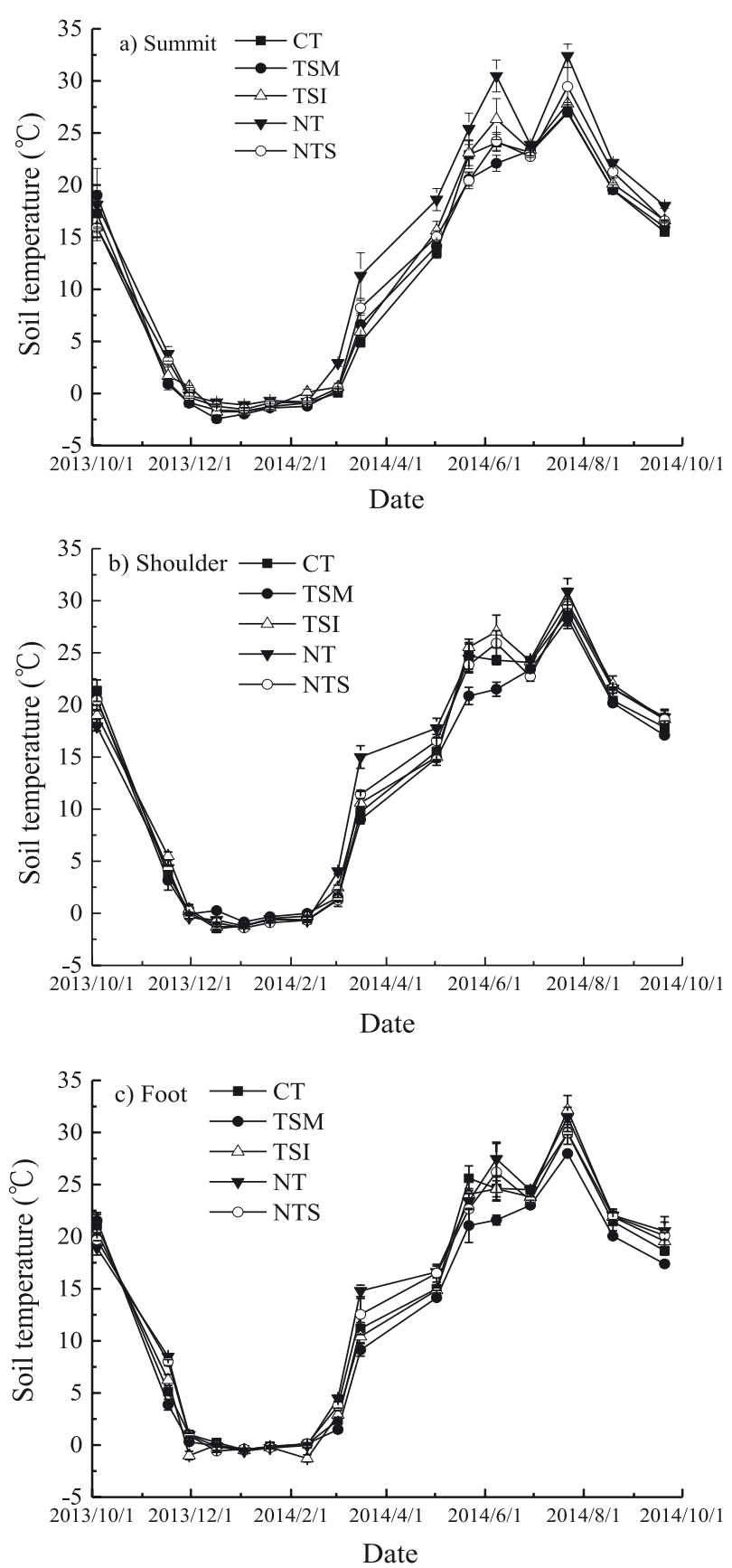

Fig. 1. The $5 \mathrm{~cm}$ soil temperature over the experimental period in the study site. $\mathrm{CT}=$ conventional moldboard plough tillage with corn straw removing; TSM $=$ conventional moldboard plough tillage with corn straw mulching on soil surface; TSI = conventional moldboard plough tillage with corn straw incorporating into soil; NT = no-tillage with corn straw removing; NTM $=$ no-tillage with corn straw mulching on soil surface. 
soil moisture, and soil respiration were determined by repeatedly measuring analysis of variance (ANOVA). The difference in $\mathrm{Q}_{10}$ values under different tillage and straw mulch treatments, annual carbon emissions, and $\mathrm{Q}_{10}$ values under difference slope position were tested by one-way ANOVA. The correlation between soil respiration rates and soil temperature were explored using exponential
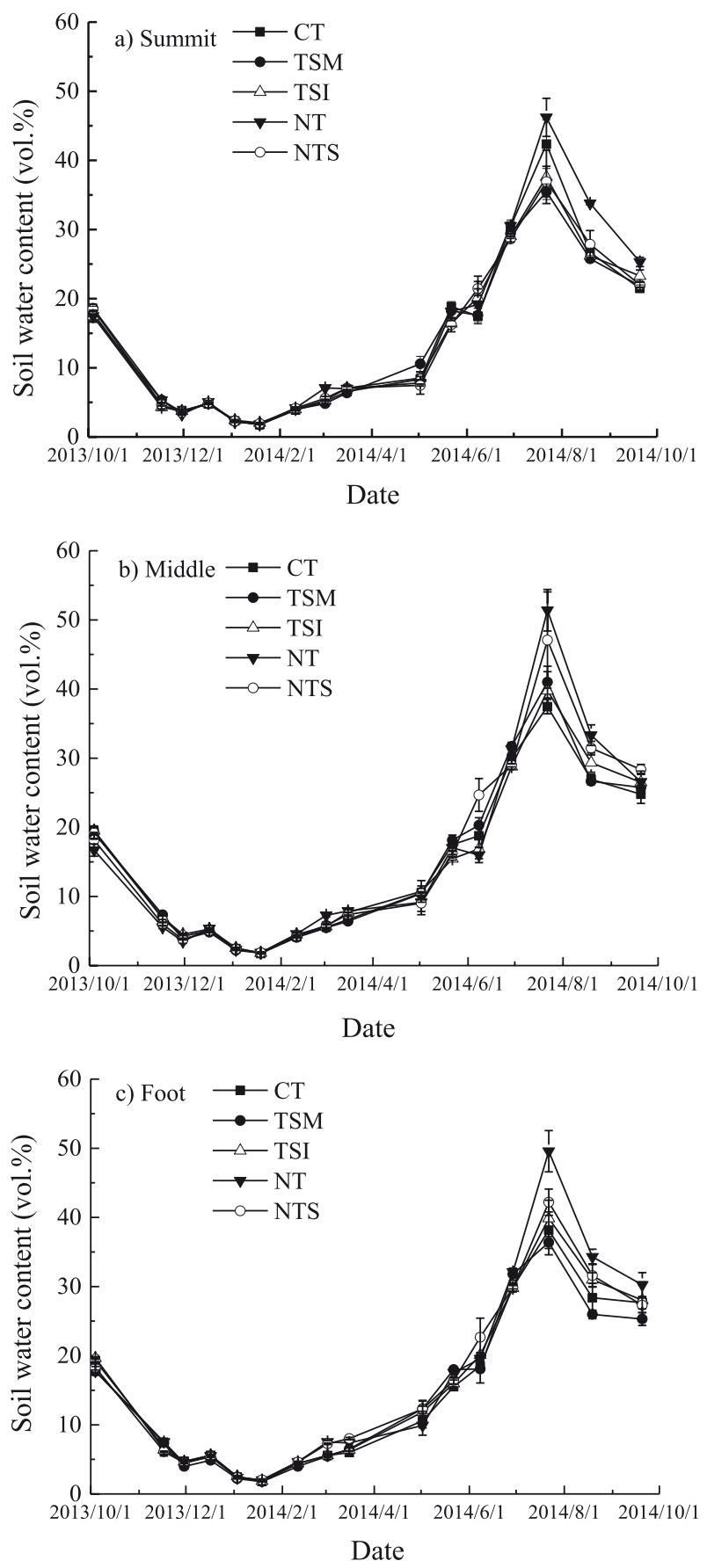

Fig. 2. The $5 \mathrm{~cm}$ soil water content over the experimental period in the study site. $\mathrm{CT}=$ conventional moldboard plough tillage with corn straw removing; TSM $=$ conventional moldboard plough tillage with corn straw mulching on soil surface; TSI $=$ conventional moldboard plough tillage with corn straw incorporating into soil; $\mathrm{NT}=$ no-tillage with corn straw removing; $\mathrm{NTM}=$ no-tillage with corn straw mulching on soil surface. regression, which was best correlated and was also used to calculate temperature sensitivity $\left(\mathrm{Q}_{10}\right)$. Correlations between soil respiration and soil moisture were explored by linear regression, which was best correlated. All statistical analyses were performed at a significance level of 0.05 using SPSS 16.0.

\section{Results}

\section{Soil Microclimate}

There was visible seasonal variability of soil temperature and moisture during the monitoring period, with the highest soil temperature and soil moisture in midJuly and the lowest soil temperature and soil moisture in early January (Figs 1-2). Slope positions had significant effects on soil temperature $(p<0.001$, Table 1, Fig. 1) and soil moisture $(p<0.001$, Table 1, Fig. 1) during the monitoring period. Annual average soil temperature was $0.26-2.37^{\circ} \mathrm{C}$ higher in the foot position than that in the summit position under various treatments; and annual average moisture was $0.35-1.73 \%$ higher in the foot position than that in the summit position under various treatments.

Soil temperature and soil moisture in the shoulder position were lower than the foot position and higher than the summit position. The difference in soil temperature and soil moisture between shoulder position and the other slope positions also varied during the experimental period. Significantly $(p<0.001)$ high soil temperature and soil moisture were recorded in no-till treatments (Table 1, Figs 1-2). Soil temperature in the summit position was higher in NT treatments than in the CT treatment (Fig. 1). Applying straw mulch showed a decreasing trend in soil temperature and soil moisture during different seasons $(p<0.001$, Table 1, Fig. 1). No significant effects of straw mulch on soil moisture were found in the experimental period. Significant interaction of slope position with tillage treatment on soil temperature $(p<0.01)$ and soil moisture

Table 1. Results (F-values) of repeated measures ANOVA for average soil temperature (AST), average soil moisture (ASM), and annual total soil respiration (TSR) in monitoring periods.

\begin{tabular}{|c|c|c|c|}
\hline Source of variation & AST & ASM & TSR \\
\hline Slope position (P) & $76.06^{* * *}$ & $36.41^{* * *}$ & $66.02^{* * *}$ \\
\hline Tillage (T) & $85.07^{* * *}$ & $43.16^{* * *}$ & $4.08^{\text {ns }}$ \\
\hline Mulching (M) & $40.83^{* * *}$ & $3.22^{\text {ns }}$ & $8.80^{* *}$ \\
\hline $\mathrm{P} \times \mathrm{T}$ & $9.75^{* *}$ & $4.18^{*}$ & $2.03^{\text {ns }}$ \\
\hline $\mathrm{P} \times \mathrm{M}$ & $4.70^{* *}$ & $2.44^{\mathrm{ns}}$ & $1.04^{\mathrm{ns}}$ \\
\hline $\mathrm{T} \times \mathrm{M}$ & $0.03^{\text {ns }}$ & $2.91^{\text {ns }}$ & $0.55^{\text {ns }}$ \\
\hline $\mathrm{P} \times \mathrm{T} \times \mathrm{M}$ & $13.91^{* * *}$ & $0.02^{\text {ns }}$ & $4.89^{* *}$ \\
\hline
\end{tabular}

$*, * *, * * *$ : statistically significant at $p<0.05,0.01$, and 0.001 , respectively; ns: statistically insignificant. 
$(p<0.05)$ were observed in the experimental period (Table $1)$. Tillage increased the difference between the summit and foot positions. Slope position had a strong interaction with straw mulch for soil temperature $(p<0.01)$, but no such interactions were observed for soil moisture (Table 1). In addition, the significant interactive effects on soil temperature of slope position, tillage, and straw mulch were also observed $(p<0.001$, Table 1$)$.

\section{Annual Soil Respiration under Different Treatments}

Soil respiration showed a strong seasonal pattern, with the highest microbial activity in July and the lowest in January (Fig. 3). Slope position had significant effects on soil respiration $(p<0.001$, Table 1, Fig. 3). Soil respiration rates of the three landscape positions were reduced in the following order: foot $>$ shoulder $>$ summit positions under different tillage and straw mulch treatments (Fig. 3), and the difference of annual soil carbon emissions between the foot and summit positions was significant (Fig. 3). Tillage alone did not have any significant effect on annual soil carbon emissions $(p>0.05$, Table 1$)$. But NT treatment significantly increased soil respiration rates during June and September. For example, in the summit position, soil respiration rates under NT treatment were higher than CT treatments in the periods from 29 June to 20 September 2014 (Fig. 3). Straw mulch significantly increased soil respiration $(p<0.01$, Table 1$)$. Meanwhile, straw mulch significantly decreased soil temperature $(p<0.001)$ and had no significant effect on soil moisture. These results indicated that straw mulch itself led to the release of $\mathrm{CO}_{2}$. In addition, we observed the visible interactive effects on soil respiration of slope position, tillage, and straw mulch $(p<0.01$, Table 1$)$. In the shoulder position, soil respiration rates were lower in NTM and TSM treatments than other treatments in winter. In the foot position, soil respiration rates under NTM and NT were lower than other treatments in winter; soil respiration rates under TSI were highest in summer and autumn. Tillage and straw mulch could affect soil respiration in different slope positions by changing soil temperature, soil moisture, and soil erosion rate.

\section{Dependence of Soil $\mathrm{CO}_{2}$ Efflux on Soil Temperature and Soil Moisture}

Soil respiration rates increased exponentially with increasing soil temperature in all treatments (Table 2). The exponential function showed a good fit for representing the dependence of soil $\mathrm{CO}_{2}$ efflux on soil temperature. Soil temperature explained $74-92 \%$ of soil respiration using the exponential equation. Soil moisture was also an important factor controlling soil respiration, and soil moisture alone explained $61-84 \%$ of the variation in soil respiration using the linear function (Table 2).

The average $Q_{10}$ values of soil respiration in the monitoring year were 2.07, 2.25, 2.16, 2.11, and 2.16 in the CT, TSM, TSI, NT, and NTS treatments, respectively, and the difference among different treatments was not
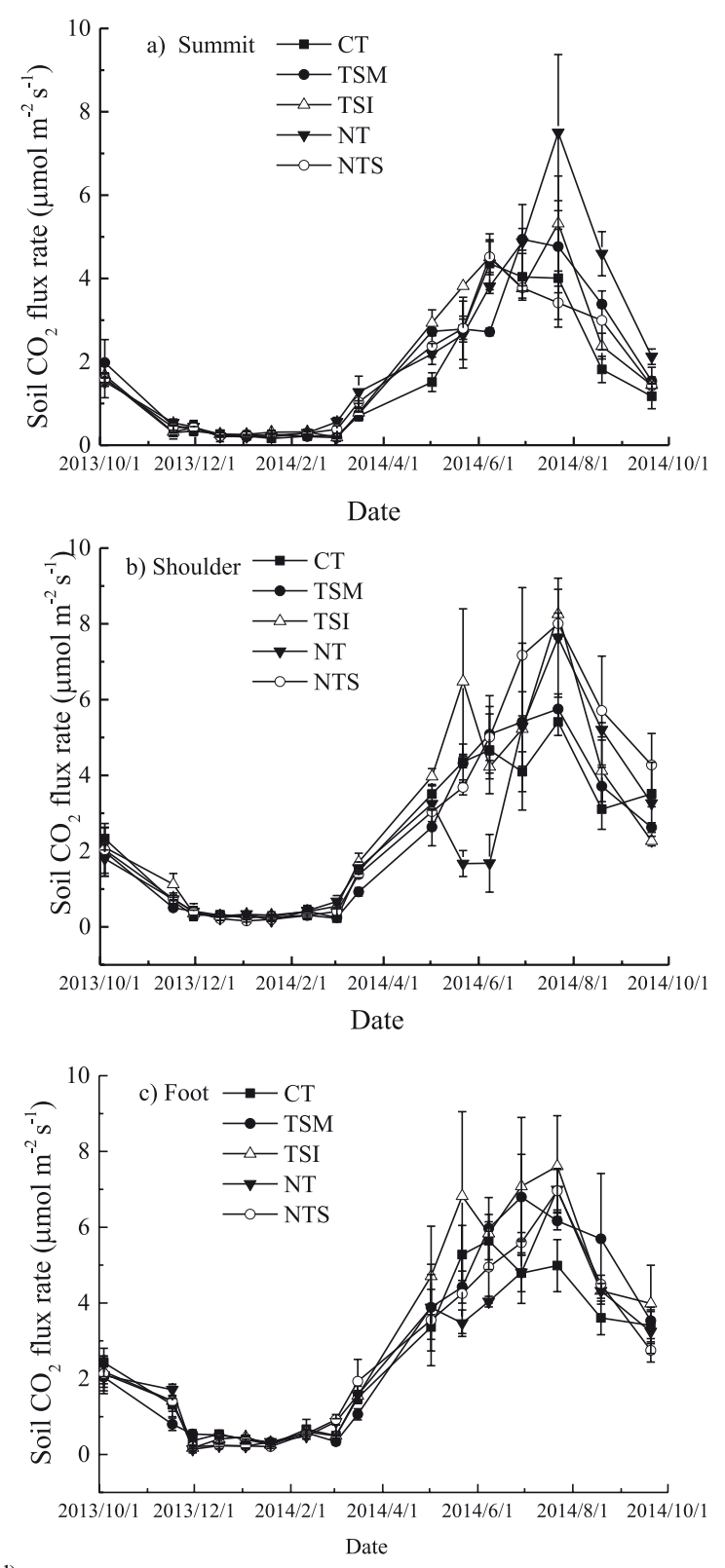

d)

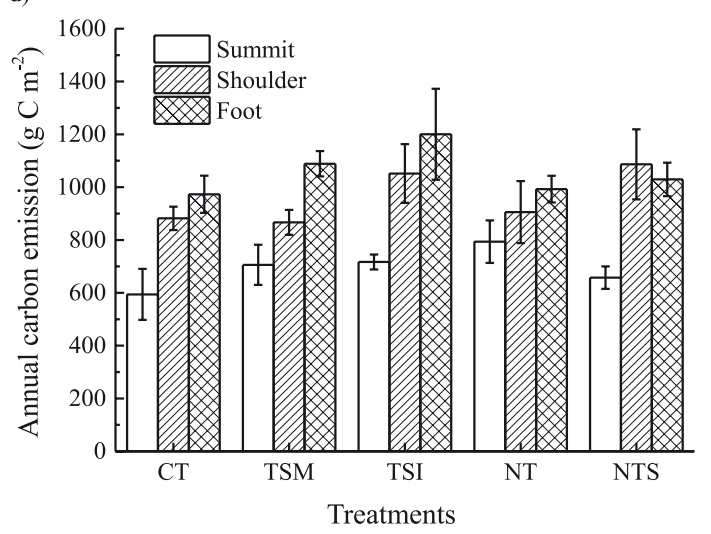

Fig. 3. Soil $\mathrm{CO}_{2}$ fluxes over a one year period from October 2013 to September 2014. CT $=$ conventional moldboard plough tillage with corn straw removing; TSM = conventional moldboard plough tillage with corn straw mulching on soil surface; TSI = conventional moldboard plough tillage with corn straw incorporating into soil; NT $=$ no-tillage with corn straw removing; NTM = no-tillage with corn straw mulching on soil surface. The vertical bars indicate standard error $(n=3)$. 
Table 2. Relationship between soil respiration and soil temperature $\left({ }^{\circ} \mathrm{C}\right)$ and soil water content $(\%)$ under different treatments.

\begin{tabular}{|c|c|c|c|c|c|c|c|c|}
\hline \multirow{2}{*}{\multicolumn{2}{|c|}{ Treatments }} & \multicolumn{7}{|c|}{ Estimated parameters } \\
\hline & & \multicolumn{4}{|c|}{$\mathrm{R}=\mathrm{a} \times \mathrm{e}^{\mathrm{bT}}$} & \multicolumn{3}{|c|}{$\mathrm{R}=\mathrm{AW}+\mathrm{B}$} \\
\hline $\begin{array}{l}\text { Tillage and } \\
\text { straw mulch } \\
\text { treatments }\end{array}$ & $\begin{array}{c}\text { Topographic } \\
\text { position }\end{array}$ & a & b & $\mathrm{R}^{2}$ & $\mathrm{Q}_{10}$ & A & B & $\mathrm{R}^{2}$ \\
\hline \multirow{3}{*}{ CT } & Summit & $0.348 \pm 0.071$ & $0.096 \pm 0.009$ & 0.874 & $2.626 \pm 0.219^{\mathrm{e}}$ & $0.102 \pm 0.011$ & $0.156 \pm 0.205$ & 0.623 \\
\hline & Shoulder & $0.709 \pm 0.107$ & $0.073 \pm 0.006$ & 0.863 & $2.078 \pm 0.084^{\mathrm{abc}}$ & $0.147 \pm 0.013$ & $0.135 \pm 0.226$ & 0.736 \\
\hline & Foot & $0.866 \pm 0.126$ & $0.066 \pm 0.006$ & 0.835 & $1.937 \pm 0.028^{\mathrm{a}}$ & $0.138 \pm 0.016$ & $0.503 \pm 0.282$ & 0.619 \\
\hline \multirow{3}{*}{ TS } & Summit & $0.490 \pm 0.086$ & $0.087 \pm 0.008$ & 0.862 & $2.414 \pm 0.204^{\mathrm{cde}}$ & $0.142 \pm 0.009$ & $-0.151 \pm 0.157$ & 0.832 \\
\hline & Shoulder & $0.64 \pm 0.102$ & $0.083 \pm 0.007$ & 0.864 & $2.309 \pm 0.061^{\text {abcde }}$ & $0.155 \pm 0.011$ & $-0.037 \pm 0.210$ & 0.798 \\
\hline & Foot & $0.934 \pm 0.186$ & $0.074 \pm 0.009$ & 0.753 & $2.098 \pm 0.04^{\mathrm{abc}}$ & $0.198 \pm 0.015$ & $-0.041 \pm 0.260$ & 0.792 \\
\hline \multirow{3}{*}{ TSI } & Summit & $0.463 \pm 0.064$ & $0.088 \pm 0.006$ & 0.924 & $2.507 \pm 0.386^{\mathrm{de}}$ & $0.131 \pm 0.013$ & $0.058 \pm 0.227$ & 0.673 \\
\hline & Shoulder & $0.635 \pm 0.132$ & $0.083 \pm 0.008$ & 0.837 & $2.326 \pm 0.191^{\text {abcde }}$ & $0.172 \pm 0.02$ & $0.202 \pm 0.374$ & 0.613 \\
\hline & Foot & $1.097 \pm 0.205$ & $0.065 \pm 0.007$ & 0.742 & $1.957 \pm 0.162^{\mathrm{a}}$ & $0.187 \pm 0.021$ & $0.263 \pm 0.393$ & 0.625 \\
\hline \multirow{3}{*}{ NT } & Summit & $0.526 \pm 0.124$ & $0.077 \pm 0.008$ & 0.777 & $2.138 \pm 0.142^{\mathrm{abcd}}$ & $0.152 \pm 0.010$ & $-0.151 \pm 0.191$ & 0.833 \\
\hline & Shoulder & $0.578 \pm 0.142$ & $0.082 \pm 0.009$ & 0.747 & $2.362 \pm 0.318^{\text {bcde }}$ & $0.150 \pm 0.009$ & $-0.107 \pm 0.189$ & 0.846 \\
\hline & Foot & $0.717 \pm 0.107$ & $0.071 \pm 0.006$ & 0.852 & $2.084 \pm 0.165^{\mathrm{abc}}$ & $0.133 \pm 0.010$ & $0.301 \pm 0.202$ & 0.799 \\
\hline \multirow{3}{*}{ NTS } & Summit & $0.666 \pm 0.01$ & $0.066 \pm 0.006$ & 0.796 & $1.959 \pm 0.122^{\mathrm{ab}}$ & $0.108 \pm 0.011$ & $0.203 \pm 0.192$ & 0.665 \\
\hline & Shoulder & $0.723 \pm 0.166$ & $0.081 \pm 0.009$ & 0.782 & $2.327 \pm 0.205^{\text {abcde }}$ & $0.186 \pm 0.012$ & $-0.119 \pm 0.237$ & 0.838 \\
\hline & Foot & $0.754 \pm 0.122$ & $0.074 \pm 0.006$ & 0.84 & $2.210 \pm 0.279^{\mathrm{abcd}}$ & $0.161 \pm 0.012$ & $0.097 \pm 0.235$ & 0.787 \\
\hline
\end{tabular}

R: soil respiration; T: soil temperature at $5 \mathrm{~cm} ; \mathrm{W}$ : soil water content at $5 \mathrm{~cm} ; \mathrm{Q}_{10}$ : sensitivity of $\mathrm{CO}_{2}$ emission to a $10^{\circ} \mathrm{C}$ increase in soil temperature for each treatment; $\mathrm{Q}_{10}$ values within a column followed by the same letter are not significantly different at $p<0.05$.

significant at $p<0.05$ (Fig. 4). Slope position affected $\mathrm{Q}_{10}$ values. In CT, TSM, and TSI treatments, the $\mathrm{Q}_{10}$ values showed a decreasing trend from summit to foot, and the difference between the summit and foot positions in CT and TSI treatment was significant $(p<0.05)$. However, NT treatment increased $Q_{10}$ values from summit to foot position, but the difference was not significant among different positions (Table 2).

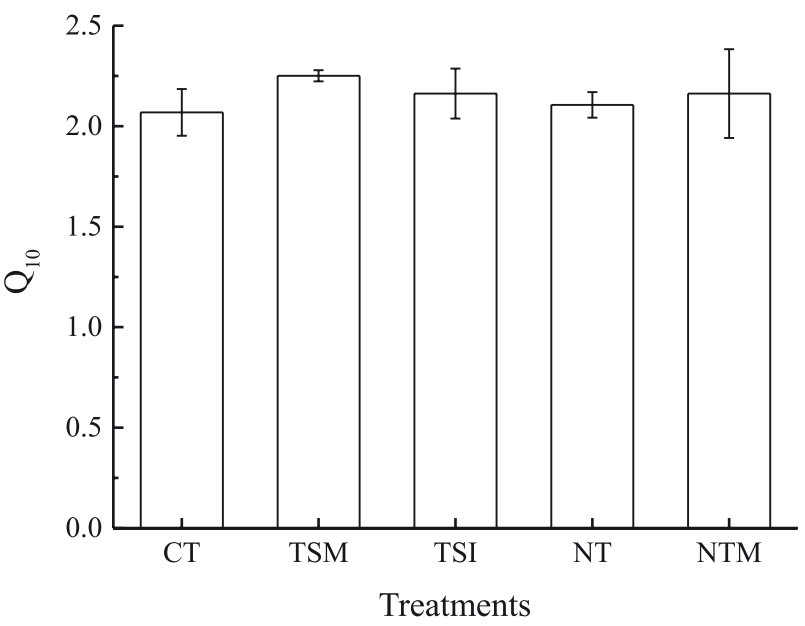

Fig. 4. The $\mathrm{Q}_{10}$ values in different tillage and straw mulch treatments during the monitoring period

\section{Discussion}

\section{Effects of Tillage and Straw Mulch on Soil Respiration}

Many studies have reported the effect of tillage and straw mulch on soil respiration, with no consistent trend $[4,24,36]$. These inconsistent results could be attributed to the differences in climatic conditions, soil types, farm management practices, and the timing and duration of measurements [4]. The majority of studies showed that tillage and straw mulching increase soil respiration through increased substrate (C) and soil aeration [7, 37-38]. However, in our study we found no such trend (Table 1, Fig. 3) as annual soil respiration in the summit treatment under NT treatment was higher than that in the CT treatment ( $p<0.05$, Fig. 3). Our results are consistent with those of Ahamad et al. [14], Elder and Lal [15], and Glenn et al. [39], who reported a similar trend. Tillage treatment significantly affected soil temperature and soil moisture, but had no significant influence on soil respiration $(p<0.001$, Table 1$)$. This lack of any significant effect of tillage treatment on soil respiration in our study ( $p>0.05$, Table 1) could be related to the fact that notill decreases soil microbial respiration through reduced soil physical disturbance, which then leads to increasing aggregate stability and build of SOM [13, 40]. This would offset the increase of soil respiration by changing soil temperature and soil moisture. The short-term effects of 
tillage result from the physical soil disturbance that occurs during plowing and the location of crop residues [41]. The magnitude of $\mathrm{CO}_{2}$ losses from soil due to tillage practices is highly related to the intensity of soil disturbance caused by tillage. However, the effects would disappear in a short period [24, 42-43]. We did not monitor short-term effects in this study. This may underestimate the emissions in tillage treatments.

In the present study, straw input had a significant $(p<0.01)$ effect on total soil respiration (Table 1). TSI treatment had the highest annual total soil respiration (992 $\mathrm{g} \mathrm{C} \mathrm{m}^{-2}$, average annual total values of different slope positions) than other treatments, probably due to better contact between $\mathrm{C}$ in the added straw mulch and soil microorganisms. Kennedy and Arceneaux [41] and Yadvinder-Singh et al. [44] also reported that the incorporation of plant residues resulted in increased organic $\mathrm{C}$ mineralization compared with leaving them on the soil surface, where the added $\mathrm{C}$ is less accessible to soil microorganisms. Straw itself was an important source of $\mathrm{C}$ inputs, which enhance microbial biomass and thus $\mathrm{CO}_{2}[19-20,22-23]$, and the amount of $\mathrm{CO}_{2}$ increased as the amount of straw increased [21]. Glenn et al. [39] has suggested that at least $25 \%$ of $\mathrm{C}$ in maize residues was lost due to microbial respiration during this non-growing period. Fu et al. [45] also has suggested that residue application might cause a net loss of soil carbon in agroecosystems. On the other hand, straw input treatment had a significant effect on soil temperature $(p<0.001$, Table 1), which could decrease soil respiration rates.

\section{Effect of Slope Position on Soil Respiration}

In the present study, we observed high annual soil microbial respiration rates in the foot than those in the shoulder and upper slope (Fig. 1), and the slope position had significant effects on soil respiration $(p<0.001$, Table 1). Slope position indirectly changed soil respiration by causing variability of soil temperature, soil moisture, soil microbial biomass, and plant growth, etc. [29, 31, 46]. In this study, significant correlations of soil microbial respiration with soil temperature and soil moisture at the temporal and spatial scales (Table 2) indicate that these two factors control soil microbial growth, activity, and respiration [47]. Soil temperature and soil moisture could explain $74-92 \%$ and $61-84 \%$ of the variation in soil respiration. Slope position significantly increased soil temperature and soil moisture in foot position $(p<0.001$, Table 1). This result was consistent with Van Hemelryck et al. [28], who suggested that the temperature measured at depositional positions was $0.5^{\circ} \mathrm{C}$ higher than that measured at eroded positions. However, some studies have shown that higher soil temperature was observed in the upper slope $[29,46]$. The differences in soil temperature and soil moisture content at different positions were likely due in part to different physical and chemical properties (soil texture, bulk density, soil organic material) of soil caused by erosion $[29,48]$. On the other hand, slope orientation or aspect was also an important factor affecting soil temperature and soil moisture. Our study site was located on a north-facing hillslope, and the foot position would receive more solar radiation than that of the flatter summit position. In contrast, the study sites of Xu and Wan [46] and Wei et al. [29] were located on a south-facing hillslope, and the summit position would have higher soil temperature, so more attention needs to be paid to slope orientation in future studies. Soil moisture and soil temperature were all positively correlated with soil respiration, indicating that the two factors were all limiting for soil respiration in our study site. Soil temperature and soil moisture were all higher in the foot position than in the summit position. In addition, greater carbon and nitrogen nutrient availability in the foot position caused by erosion could also directly simulate auto- and heterotrophic activities and respiration $[28,49]$, and this would increase the differences among slope positions. In addition, slope position also interacts with tillage and straw mulch treatments to influence soil temperature $(p<0.001)$ and respiration $(p<0.01$, Table 1$)$. Tillage and straw mulch could change soil erosion and then affect soil respiration [50]. In our study, the difference of annual soil respiration among different slope positions in CT were higher than that in NT treatment (Fig. 3), the reasons may be that tillage increased soil erosion rates and redistribution. So the effect of conservation tillage on soil erosion could be paid more attention in further studies.

\section{Dependence of Soil $\mathrm{CO}_{2}$ Efflux and $\mathrm{Q}_{10}$ on Soil Temperature and Moisture}

Previous studies identified soil temperature and soil moisture as major physical factors affecting soil respiration [3, 29, 51]. Soil temperature and moisture can directly influence root and microbial activities and respiration $[28,46]$ and/or indirectly via altering plant growth and belowground $\mathrm{C}$ allocation, as well as litter decomposition [52]. Some studies have indicated that soil respiration is mainly controlled by soil temperature [3-4], while others suggest that soil moisture is also a dominant factor, especially in arid and semiarid areas [3, 11, 53]. Some studies have reported that the effect of soil moisture and soil temperature on soil respiration change during the monitoring period [29]. In our study, soil temperature and soil moisture were all important factors controlling soil microbial respiration (Table 2). The correlation between soil respiration and soil temperature was exponential, while the correlation between soil respiration and soil temperature was linear (Table 2). These results indicated that soil moisture and soil temperature may all be limited factors to affect soil respiration in our study site, and increasing soil temperature and soil moisture had a positive effect on soil respiration.

$\mathrm{Q}_{10}$ values ranged from 1.94 to 2.63 in this study and were similar to the range of values (1.42-2.32) reported in the plateau area [3]. Slope position had a visible effect on $\mathrm{Q}_{10}$; the $\mathrm{Q}_{10}$ values decreased from summit to foot under CT, TSM, and TSI treatments; and the difference of $\mathrm{Q}_{10}$ values between summit and foot position under $\mathrm{CT}$ and 
TSI treatments was significant $(p<0.05$, Table 2$)$. However, the difference of $\mathrm{Q}_{10}$ values among slope position under NT and NTS was not visible, and the $Q_{10}$ values even had the tendency to increase from summit to foot under NTS treatment. Those results indicated that the $\mathrm{Q}_{10}$ values may be changed by tillage and straw mulch treatment along the slope position. The $\mathrm{Q}_{10}$ value was higher at low soil moisture content [54]. Shi et al. [3] found that $\mathrm{Q}_{10}$ values were negatively correlated with average soil temperature and moisture. Tillage treatment significantly decreased soil temperature and increased temperature differences among slope position while decreasing soil moisture, which may partly explain the changes of $\mathrm{Q}_{10}$ values along the slope position. On the other hand, Wang et al. [55] found significant negative correlation between $\mathrm{Q}_{10}$ and $\mathrm{C}$ quality index. No-tillage changes the soil redistribution of labile carbon, and the nitrogen fraction may be another reason $[31,40]$.

\section{Conclusion}

No-till treatments enhanced soil microbial respiration mainly through increasing soil moisture and soil temperature. Residue application might cause a net increase of soil respiration by $\mathrm{C}$ inputs in residues itself, although straw mulch may decrease soil microbial activities by decreasing soil temperature. Slope position had significant effects on soil respiration among various tillage and straw mulch treatments, and annual total soil respiration followed a descending sequence as foot $>$ shoulder $>$ summit positions. Tillage and straw mulch treatments may indirectly meditate spatial variability of soil respiration by affecting soil erosion rate, soil moisture, and soil temperature. Soil temperature and soil moisture were all important in regulating spatial and temporal variability of soil respiration in semiarid cropland in the plateau. The temporal variability of soil respiration in each treatment was explained by an exponential relationship between soil respiration and soil temperature, and a linear relationship between soil respiration and soil water content. $Q_{10}$ values showed visible spatial variability in tillage treatments, but the spatial variability disappeared in no-till treatments. These results indicated that the tillage pattern may change soil temperature sensitivity of soil respiration in sloping cropland, which should be paid more attention in future studies.

\section{Acknowledgments}

This work was supported by the National Key Research and Development Program of China (2016YFD0300203-3), the Scientific Research Foundation for doctors of Henan Normal University (qd12129, qd12126), the Key project of science and technology research of Henan Provincial Department of Education (14B180008), and an International Atomic Energy Agency Technical Contract (No. 17680). The authors thank Xiaohui Li for his help in setting up the experiment and for soil respiration measurements in the field. We acknowledge the anonymous reviewers and issue editor for their constructive comments on this paper.

\section{References}

1. BOND-LAMBERTY B., BRONSON D., BLADYKA E., GOWER S.T. A comparison of trenched plot techniques for partitioning soil respiration. Soil Bio. Biochem. 43, 2108, 2011.

2. RAICH J.W., POTTER C.S., BHAGAWATI D. International variability in global soil respiration. Global Change Biol. 8, 800, 2002

3. SHI W.Y., YAN M.J., ZHANG J.G., GUAN J.H., DU S. Soil $\mathrm{CO}_{2}$ emissions from five different types of land use on the semiarid Loess Plateau of China, with emphasis on the contribution of winter soil respiration. Atmos. Environ. 88, 74, 2014.

4. SHI X.H., ZHANG X.P., YANG X.M., DRURY C.F., MCLAUGHLIN N.B., LIANG A.Z., FAN R.Q., JIA S.X. Contribution of winter soil respiration to annual soil $\mathrm{CO}_{2}$ emission in a Mollisol under different tillage practices. Global Biogeochem. Cy. 26, 1, 2012.

5. SMITH P. Agricultural greenhouse gas mitigation potential globally, in Europe and in the UK: what have we learnt in the last 20 years? Global Change Biol. 18, 35, 2012.

6. GODFRAY H.C.J., BEDDINGTON J.R., CRUTE I.R., HASSAS L., LAWRENCE D., MUIR J.F., PRETTY J., ROBINSON S., THOMAS S.M., TOULMIN C. Food security: the challenge of feeding 9 billion people. Science. 327, 812, 2010

7. NEOGI S., BHATTACHARYYA P., ROY K.S., PANDA B.B., NAYAK A.K., RAO K.S., MANNA M.C. Soil respiration, labile carbon pools, and enzyme activities as affected by tillage practices in a tropical rice-maize-cowpea cropping system. Environ. Monit. Assess. 186, 4223, 2014.

8. SMITH F., BRYE K.R., GBUR E.E., CHEN P.Y., KORTH $\mathrm{K}$. Long-term residue management effects on soil respiration in a wheat-soybean double-crop system. Soil Sci. 179, 118, 2014.

9. ABDALLA M., OSBORNE B., LANIGAN G., FORRISTAL D., WILLIAMS M., SMITH P., JONES M.B. Conservation tillage systems: a review of its consequences for greenhouse gas emissions. Soil Use Manage. 29, 199, 2013.

10. BUYSSE P., SCHNEPF-KISS A., CARNOL M., MALCHAIR S., ROISIN C., AUBINET M. Fifty years of crop residue management have a limited impact on soil heterotrophic respiration. Agr. Forest Meteorol. 180, 102, 2013.

11. WOLIŃSKA A., STEPNIEWSKA Z., SZAFRANEKNAKONIECZNA A. 2011. Effect of selected physical parameters on respiration activities in common Polish mineral soils. Pol. J. Environ. Stud. 20 (4), 1075, 2011.

12. WOLIŃSKA A., SZAFRANEK-NAKONIECZNA A., BANACH A., REKOSZ-BURLAGA H., GORYLUKSALMONOWICZ A., BIASZCZYK M., STEPNIEWSKA Z., GÓRSKI A. Biological degradation of agricultural soils from Lublin region (SE Poland). International Journal of Current Microbiology and Applied Sciences, 3 (11), 558, 2014.

13. PAUSTIAN K., SIX J., ELLIOTT E.T., HUNT H.W. Management options for reducing $\mathrm{CO}_{2}$ emissions from agricultural soils. Biogeochemistry. 48, 147, 2000. 
14. AHAMAD S., LI C., DAI G., ZHAN M., WANG J., PAN S., CAO C. Greenhouse gas emission from direct seeding paddy field under different rice tillage systems in central china. Soil Till. Res. 106, 54, 2009.

15. ELDER J.W., LAL R. Tillage effects on gaseous emissions from an intensively farmed organic soil in North Central Ohio. Soil Till. Res. 98, 45, 2008.

16. REGINA K., ALAKUKKU L. Greenhouse gas fluxes in varying soils types under conventional and no-tillage practices. Soil Till. Res. 109, 144, 2010.

17. HENDRIX P.F., HAN C.R., GROFFMAN P.M. Soil respiration in conventional and no-tillage agroecosystems under different winter cover crop rotations. Soil Till. Res. 12, 135, 2005.

18. KALLENBACH C., ROLSTON D.E., HORWATH W.R. Cover cropping affects soil $\mathrm{N}_{2} \mathrm{O}$ and $\mathrm{CO}_{2}$ emissions differently depending on type of irrigation. Agric. Ecosyst. Environ. 137, 251, 2010.

19. BAVIN T.K., GRIFFIS T.J., BAKER J.M., VENTEREA R.T. Impact of reduced tillage and cover cropping on the greenhouse gas budget of a maize/soybean rotation ecosystem. Agric. Ecosyst. Environ. 134, 234, 2009.

20. OORTS K., MERCKX R., GRÉHAN E., LABREUCHE J., NICOLARDOT B. Determinants of annual fluxes of $\mathrm{CO}_{2}$ and $\mathrm{N}_{2} \mathrm{O}$ in long-term no-tillage and conventional tillage systems in northern France. Soil Till. Res. 95, 133, 2007.

21. LENKA N.K., LAL R. Soil aggregation and greenhouse gas flux after 15 years of wheat straw and fertilizer management in a no-till system. Soil Till. Res. 126, 78, 2013.

22. ZAMAN M., DI H.J., SAKAMOTO K., GOTO S., HAYASHI H., INUBUSHI K. Effect of sewage sludge compost and chemical fertilize application on microbial biomass and $\mathrm{N}$ mineralization rates. Soil Sci. Plant Nutr. 48, 195, 2002.

23. 23. INUBUSHI K., NGUYEN M.L., GOTO S., KANEKO F., YONEYAMA T. Nitrogen mineralization, $\mathrm{N}_{2} \mathrm{O}$ production and soil microbiological properties as affected by long-term applications of sewage sludge composts. Biol. Fert. Soils. 40, 101, 2004.

24. AL-KAISI M., YIN X. Tillage and crop residues effects on soil carbon and carbon dioxide emission in corn-soybean rotations. J. Environ. Qual. 34, 437, 2005.

25. REICOSKY D., REEVES D.W., PRIOR S.A., RUNION G.B., ROGERS H.H., RAPER R.L. Effects of residue management and controlled traffic on carbon dioxide and water loess. Soil Till. Res. 52, 153, 1999.

26. FIENER P., DLUGOß V., KORRES W., SCHNEIDER K. Spatial variability of soil respiration in a small agricultural watershed-Are patterns of soil redistribution important? Catena. 94, 3, 2012.

27. PARKIN T.B,, KASPAR T.C., SENWO Z., PRUEGER J.H., HATFIELD J.L. Relationship of soil respiration to crop and landscape in the Walnut Creek watershed. J. Hydrometeorol. 6, 812, 2005 .

28. VAN HEMELRYCK H., GOVERS G., VAN OOST K., MERCKX R. Evaluating the impact of soil redistribution on the in situ mineralization of soil organic carbon. Earth Surf. Process. Landforms 36, 427, 2011.

29. WEI S.C., ZHANG X.P., MCLAUGHLIN N.B., LIANG A.Z., JIA S.X., CHEN X.W., CHEN X.X. Effect of soil temperature and soil moisture on $\mathrm{CO}_{2}$ flux from eroded landscape positions on black soil in Northeast China. Soil Till. Res. 144, 119, 2014.

30. VAN OOST K., QUINE T.A., GOVERS G., DE GRYZE S., SIX J., HARDEN J.W., RITCHIE J.C., MCCARTY G.W., HECKRACH G., KOSMAS C., GIRALDEZ J.V.,
MARQUES D.A., SILVA J.R., MERCKX R. The impact of agricultural soil erosion on the global carbon cycle. Science 318, 626, 2007.

31. VAN HEMELRYCK H., FIENER P., VAN OOST K., GOVERS G., MERCKX R. The effect of soil redistribution on soil organic carbon: an experimental study. Biogeosciences 7, 3971, 2010.

32. BAJRACHARYA R.M., LAL R., KIMBLE J.M. Erosion effects on carbon dioxide concentration and carbon flux from an Ohio Alfisol. Soil Sci. Soc. Am. J. 64, 694, 2000.

33. LI X.D., FU H., GUO D., LI X.D., WAN C.G. Partitioning soil respiration and assess the carbon balance in a Setariaitalic (L.) Beauv. cropland on the Loess Plateau, Northern China. Soil Bio. Biochem. 42, 337, 2010.

34. FENG X.M., WANG Y.F., CHEN L.D., FU B.J., BAI G.S. Modeling soil erosion and its response to land-use change in hilly catchments of the Chinese Loess Plateau. Geomorphology 118, 239, 2010.

35. SHARMA P., ABROL V., SHARMA R.K. Impact of tillage and mulch management on economics, energy requirement and crop performance in maize-wheat rotation in rainfed subhumid inceptisols, India. Eur. J. Agron. 34, 46, 2011.

36. YONEMURA S., NOUCHI I., NISHIMURA S., SAKURAI G., TOGAMI K., YAGI K. Soil respiration, $\mathrm{N}_{2} \mathrm{O}$ and $\mathrm{CH}_{4}$ emissions from an Andisol under conventional-tillage and no-tillage cultivation for 4 years. Biol. Fert. Soils. 50, 63, 2014.

37. BARRETO R.C., MADARI B.E., MADDOCK J.E.L., MACHADO P.L.O.A., ELENO T., FRANCHINI J., COSTA A.R. The impact of soil management on aggregation, carbon stabilization and carbon loss as $\mathrm{CO}_{2}$ in the surface layer of a Rhodic ferralsol in Souththern Brazil. Agric. Ecosyst. Environ. 132, 243, 2009.

38. ZHANG H.X., WANG H.K., FENG Z.W., PANG J.Z., LU F., OUYANG Z.Y., ZHENG H., LIU W.Z., HUI D.F. Soil temperature and moisture sensitivities of soil $\mathrm{CO}_{2}$ efflux before and after tillage in a wheat field of Loess Plateau, China. J. Environ. Science - China. 23, 79, 2011.

39. GLENN A.J., AMIRO B.D., TENUTA M., WAGNERRIDDLE C., DREWITT G., WARLAND J. Contribution of crop residue carbon to soil respiration at a northern Prairie site using stable isotope flux measurements. Agr. Forest Meteorol. 151, 1045, 2011.

40. USSIRI D.A.N., LAL R. Long-term tillage effects on soil carbon storage and carbon dioxide emissions in continuous corn cropping system from an alfisol in Ohio. Soil Till. Res. 104, 39, 2009.

41. KENNEDY C.W., ARCENEAUX, A.E. The effect of harvest residue management inputs on soil respiration and crop productivity of sugarcane. J. Am. Soc. Sugarcane Technol. 26, 125, 2006.

42. LA SCALA N. BOLONHEZI D. Pereira GT. Short-term soil $\mathrm{CO}_{2}$ emission after conventional and reduced tillage of a notill sugar cane area in southern Brazil. Soil Till. Res. 91, 244, 2006.

43. OMONODE R.A., VYN T.J., SMITH D.R., HEGYMEGI P., GÁL A. Soil carbon dioxide and methane fluxes from longterm tillage systems in continuous corn and corn-soybean rotations. Soil Till. Res. 95, 182, 2007.

44. YADVINDER-SINGH, GUPTA R.K., JAGMOHANSINGH, GURPREET-SINGH, GOBINDER- SINGH, LADHAJ.K. Placement effects on rice residue decomposition and nutrient dynamics on two soil types during wheat cropping in rice-wheat system in northwestern India. Nutr. Cy. Agroecosys. 88, 471, 2010. 
45. FU S.L., COLEMAN D.C., SCHARTZ R., POTTER R., HENDRIX P.F., CROSSLEY JR. D.A. ${ }^{14} \mathrm{C}$ distribution in soil organisms and respiration after the decomposition of crop residue in conventional tillage and no-till agroecosystems at Georgia Piedimont. Soil Till. Res. 57, 31, 2000.

46. XU W.H., WAN S.Q. Water- and Plant-mediated responses of soil respiration to topography, fire, and nitrogen fertilization in a semiarid grassland in northern China. Soil Biol. Biochem. 40, 679, 2008.

47. ZAMAN M., CHANG S.X. Substrate type, temperature, and moisture content affect gross and net soil $\mathrm{N}$ mineralization and nitrification rates in agroforestry systems. Biol. Fert. Soils 39, 269, 2004.

48. CHAN C., KAY B.D., GREGORICH E.G. Factors influencing mineralizable carbon in a landscape with variable topography. Soil Sci. 87, 495, 2007.

49. GREGORICH E.G., GREER K.J., ANDERSON D.W., LIANG B.C. Carbon distribution and losses: erosion and deposition effects. Soil Till. Res. 47, 291, 1998.

50. BHATT R., KHERA K.L. Effect of tillage and mode of straw mulch application on soil erosion in the submontaneous tract of Punjab, India. Soil Till. Res. 88, 107, 2006.

51. CHENG J.Z., LEE X.Q., THENG B.K.G., FANG B., YANG F., WANG B., ZHANG L. Spatial variability of $\mathrm{CO}_{2}, \mathrm{CH}_{4}$, and $\mathrm{N}_{2} \mathrm{O}$ fluxes during midsummer in the Steppe of Northern China. Pol. J. Environ. Stud. 23, 319, 2014.

52. WAN S.Q., NORBY R.J., LEDFORD J., WWLTZIN J.F. Responses of soil respiration to elevated $\mathrm{CO}_{2}$, air warming, and changing soil water availability in a model old-field grassland. Global Change Biol. 13, 2411, 2007.

53. LIU W.X., XU W.H., HAN Y., WANG C.G., WAN S.Q. Responses of microbial biomass and respiration of soil to topography, burning and nitrogen fertilization in a temperate steppe. Biol. Fert. Soils 44, 259, 2007.

54. GUNTIŇAS M.E., GIL-SOTRES F., LEIRÓS M.C., TRASAR-CEPEDA C. Sensitivity of soil respiration to moisture and temperature. J. Soil Sci. Plant Nut. 13, 445, 2013.

55. WANG Q., WANG D., WEN X.F., YU G.R., HE N.P., WANG R.F. Differences in SOM decomposition and temperature sensitivity among soil aggregate size classes in a temperate grasslands. Plos One. 10, e0117033, 2015. 